Thomas Gattringer, MD

Christian Enzinger, MD

Michael Khalil, MD, PhD

Petra Schwingenschuh, MD

Alexander Pichler, MD

Alexander Moser, MD

Winfried Graninger, MD

Christina Ernst, MSc

Johannes Haybaeck, MD, $\mathrm{PhD}$

Franz Fazekas, MD

Neurol Neuroimmunol

Neuroinflammation

2014;1:e1; doi: 10.1212/

NXI.0000000000000001

\section{UNUSUAL DETERIORATION IN A PATIENT WITH MULTIPLE SCLEROSIS ON NATALIZUMAB THERAPY \\ OPEN}

Natalizumab is an effective treatment in patients with highly active relapsing-remitting multiple sclerosis (RRMS). However, its positive therapeutic effects have to be weighed against the potential serious adverse event of progressive multifocal leukoencephalopathy (PML). Thus, whenever patients with MS on natalizumab develop uncommon and progressive neurologic symptoms, the suspicion of PML has to be raised. The risk of PML becomes higher with increasing duration of natalizumab treatment, prior immunosuppressive treatment, and JC virus (JCV) antibody seropositivity. ${ }^{1}$ We here report a case of MS in which unusual symptoms in the context of 5 years of natalizumab treatment and seroconversion to JCV antibody positivity led to the initial suspicion of PML and a final diagnosis of Creutzfeldt-Jakob disease (CJD).

Case report. A 42-year-old woman with RRMS was admitted because of rapidly progressive symptoms including neuropsychological deficits and severe trunk ataxia. She had received her diagnosis of MS 15 years ago. At that time, treatment with interferon- $\beta$-1b $250 \mu \mathrm{g}$ SC every other day was initiated but had to be ceased 5 months later due to severe icterus and toxic liver necrosis. Subsequently, treatment was changed to daily SC injections of glatiramer acetate $20 \mathrm{mg}$. Ten years later, she was escalated to natalizumab because of ongoing and increasing disease activity. In March 2013, after almost 5 years of monthly infusions with natalizumab, she complained of tiredness, difficulties in walking, and problems with memory and concentration. The patient was admitted to a neurorehabilitation clinic in May under the assumption of a conversion to secondary chronic progressive MS. Subsequent brain MRIs in May and June depicted neither active/new MS lesions nor other abnormalities. Nonetheless, natalizumab was stopped after a total of 60 infusions due to suspicion of PML. Serologic blood testing for the first time showed antibodies against JCV, while PCR was negative for JCV in both blood and CSF. This was when the patient was admitted to our department, where she presented with psychomotor slowing, severe cognitive impairment in multiple domains, cerebellar dysarthria, positive primitive reflexes, and pronounced trunk ataxia. A new brain MRI demonstrated T2 hyperintense bilateral symmetric signal abnormalities in the striatum with accompanying diffusion restriction (figure), characteristic of sporadic CJD (sCJD). Lumbar puncture yielded excessively high CSF tau protein levels $(8,199 \mathrm{pg} / \mathrm{mL})$ and positivity for the 14-3-3 protein.

Subsequent EEGs revealed nonepileptic diffuse generalized abnormalities without triphasic spikes. The patient had an unremarkable family history and had not undergone neurosurgical/ophthalmic interventions. She did not have unusual eating habits and had not traveled to foreign countries. Over the following weeks, she turned akinetically mutistic, showed intermittent myoclonic jerks, and finally became fully bedridden. Probable sCJD was diagnosed according to current criteria. ${ }^{2}$ The patient died 1 month after discharge to a nursing home. Brain autopsy confirmed sCJD and showed typical MS demyelination areas (figure); there was no evidence of PML (no antibody detection against JCV antigen).

Discussion. While the primary suspicion in patients with MS on natalizumab who develop unusual neurologic symptoms is certainly PML, we here present the case of such a patient in whom these symptoms were due to $\mathrm{SCJD}$. This stresses the need to scrutinize alternative diagnoses in such a scenario. Although a definite diagnosis of CJD needs autopsy confirmation, clinical, laboratory, and brain imaging features were highly suggestive of this disease in our patient and guided the patient evaluation in this direction.

In clinical practice, any relapse in patients with MS treated with natalizumab should raise suspicion of PML. In contrast to MS, symptoms in patients with PML occur more subacutely and are continuously progressive. In addition, atypical symptoms such as seizures, rapid cognitive dysfunction, hemianopia, or altered mental status suggest PML rather than active MS. The wide clinical spectrum of $\mathrm{PML}^{3}$ comes from the fact that nearly every part of the brain can be affected, which is not too dissimilar to the diffuse spongiform degeneration of CJD. However, the co-occurrence of the 4 cardinal clinical 

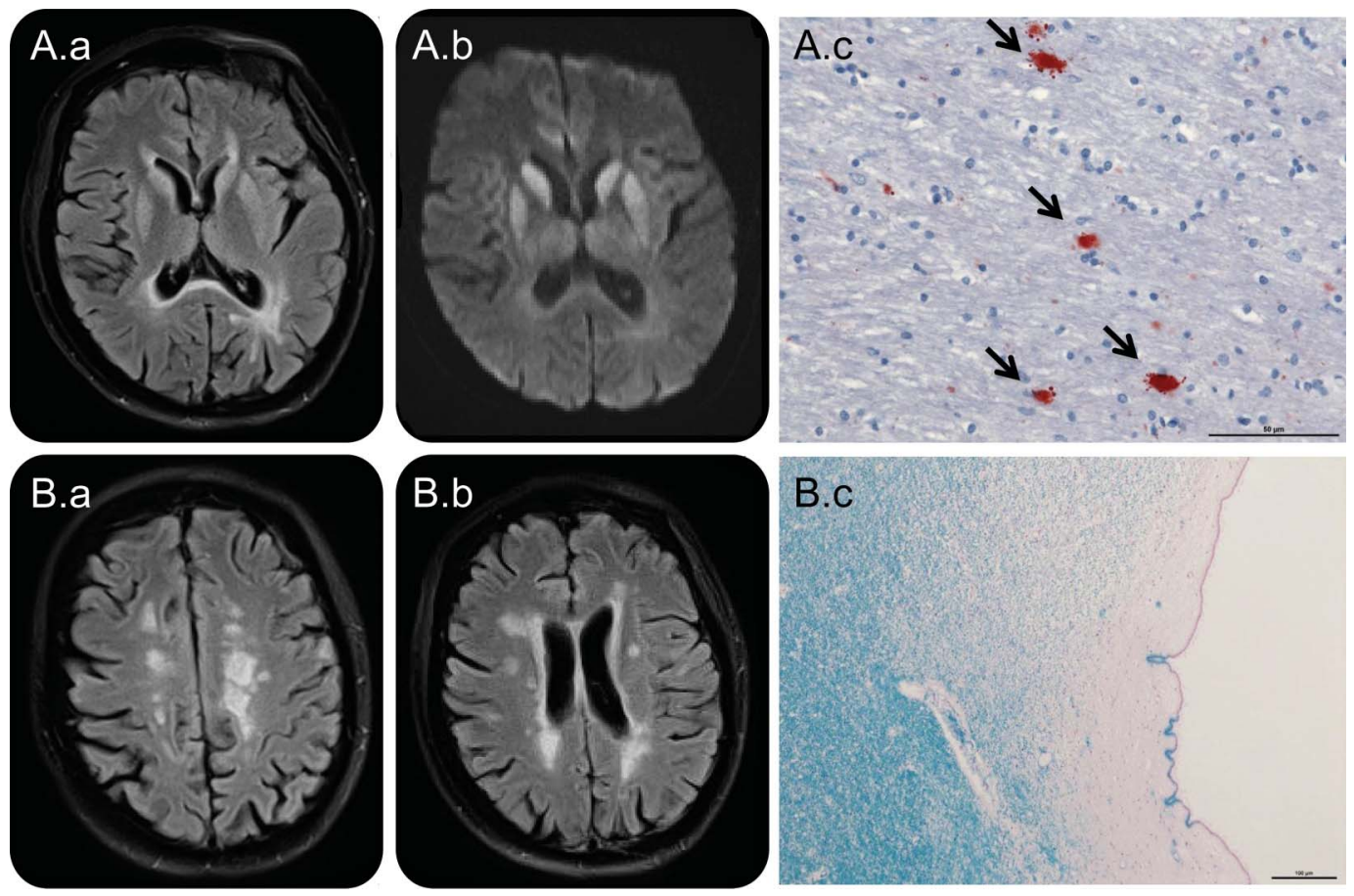

Fluid-attenuated inversion recovery (FLAIR) sequences on MRI show a symmetric hyperintensity in the caudate nucleus and putamen (A.a) and a diffusion restriction in these areas (diffusion-weighted imaging, A.b), suggestive of Creutzfeldt-Jakob disease (CJD). Histopathology ( $\times 40$ magnification) in A.c demonstrates positivity of pathologic plaques highlighted by reactivity of antibodies against the prion protein antigen (arrows; prion protein monoclonal antibody [clone 12F10], Bertin Pharma, Montigny-le-Bretonneux, France). Images B.a and B.b depict typical periventricular multiple sclerosis (MS) lesions on FLAIR MRI scans and corresponding demyelination in these areas (B.c, Klüver-Barrera staining, $\times 10$ magnification).

features (dementia, visual/cerebellar signs, pyramidal and extrapyramidal symptoms, and akinetic mutism) and especially the observation of myoclonic jerks pointed to the diagnosis of CJD in our patient. ${ }^{2}$ Another important diagnostic clue that argued against PML and supported CJD diagnosis in this case was neuroimaging. MRI patterns that distinguish PML from MS lesions have recently been published. ${ }^{4}$ In our patient, no MRI evidence for progression of MS could be seen as there were no new T2/fluidattenuated inversion recovery (FLAIR) lesions in comparison with previous available MRI scans, and there were especially no MRI changes suggestive of PML. Although basal ganglia structures are often involved in PML, ${ }^{4}$ this involvement usually occurs in a patchy and unilateral fashion, while symmetric bilateral and sharp-edged signal hyperintensity of the caudate nucleus and putamen on FLAIR and diffusion-weighted imaging sequences is very specific for CJD. ${ }^{2}$ Finally, CSF analysis was negative for JCV DNA using PCR with an ultrasensitive assay, ${ }^{5}$ whereas it was positive for the 14-3-3 protein with an excessively increased tau protein level.

Given the low incidence rate of CJD of $0.1 /$ $100,000,{ }^{6}$ it is tempting to speculate about whether the patient's primary disease or the long-term treatment with natalizumab predisposed her to develop this particular condition. However, the absence of reports on the occurrence of sCJD in patients with MS, especially those on natalizumab, and no clear pathophysiologic links make a chance association most likely.

In summary, our case report demonstrates that increased vigilance and a diligent workup of differential diagnoses are demanded in patients with MS who develop unusual symptoms and signs under therapy with natalizumab and other immunomodulating and immunosuppressive treatments.

From the Department of Neurology (T.G., C. Enzinger, M.K., P.S., A.P., F.F.), Division of Neuroradiology, Department of Radiology (C. Enzinger), Division of Rheumatology and Immunology, Department of Internal Medicine (W.G.), and Department of Neuropathology, Institute of Pathology (C. Ernst, J.H.), Medical University of Graz, Graz, Austria; and Neurorehabilitation Clinic Kapfenberg (A.M.), Kapfenberg, Austria.

Author contributions: Thomas Gattringer contributed to data collection, data analysis, interpretation of the data, and drafting of the manuscript. Christian Enzinger contributed to data analysis, interpretation of the data, drafting of the manuscript, and revision of the manuscript. Michael Khalil contributed to data analysis, interpretation of the data, and revision of the manuscript. Petra Schwingenschub contributed to data collection, data analysis, and interpretation of the data. Alexander Pichler contributed to data collection, data analysis, and interpretation of the data. Alexander Moser contributed to data collection, data analysis, and interpretation of the data. 
Winfried Graninger contributed to interpretation of the data and revision of the manuscript. Christina Ernst contributed to data collection, revision of the manuscript, and picture taking. Johannes Haybaeck contributed to data collection, data analysis, interpretation of the data, and revision of the manuscript. Franz Fazekas contributed to the design, interpretation of the data, and revision and supervision of the manuscript.

Study funding: No targeted funding reported.

Disclosure: T. Gattinger reports no disclosures. C. Enzinger has served on the advisory boards for Biogen Idec, Bayer-Schering, Merck-Serono, Novartis, and Teva Ratiopharm; has received travel grants and speaking honoraria from Biogen Idec, Teva-Aventis, Merck-Serono, Bayer-Schering, and Novartis; is on the editorial advisory board for PlosOne; is a consultant for Biogen Idec, Merck-Serono, and BayerSchering; and has received unrestricted research grants from TevaAventis, Biogen Idec, and Merck-Serono. M. Khalil has received honoraria from Bayer-Schering Pharma. P. Schwingenschuh served on national advisory boards for UCB and Novartis Austria; received funding from Boehringer-Ingelheim, Ipsen, Allergan, UCB, and Merz Pharma; and received speaker honoraria from UCB, Lundbeck, and Ipsen. A. Pichler, A. Moser, W. Graninger, C. Ernst, and J. Haybaeck report no disclosures. F. Fazekas has been an advisor for Bayer-Schering, Biogen Idec, Bristol-Myers Squibb, Genzyme, Merck-Serono, Novartis, Perceptive Informatics, Pfizer, TevaAventis, Teva Pharmceuticals LTD, and D-Pharm LTD; has been a member of DSMB; has received honoraria from Bayer-Schering, Biogen Idec, Merck-Serono, Novartis, Sanofi-Aventis, and Teva Pharmaceuticals Ltd; is on the editorial board for Cerebrovascular Diseases, Journal of Neurology, Polish Journal of Neurology and Neurosurgery, Stroke, Swiss Archives of Neurology and Psychiatry, and Multiple Sclerosis; and was on the speakers' bureau for
Bayer-Schering and Merck-Serono. Go to Neurology.org/nn for full disclosures. The Article Processing Charge was paid by the authors.

This is an open access article distributed under the terms of the Creative Commons Attribution-Noncommercial No Derivative 3.0 License, which permits downloading and sharing the work provided it is properly cited. The work cannot be changed in any way or used commercially.

Received December 13, 2013. Accepted in final form January 22, 2014.

Correspondence to Dr. Gattringer: thomas.gattringer@medunigraz.at

1. Bloomgren G, Richman S, Hotermans C, et al. Risk of natalizumab-associated progressive multifocal leukoencephalopathy. N Engl J Med 2012;366:1870-1880.

2. Zerr I, Kallenberg K, Summers DM, et al. Updated clinical diagnostic criteria for sporadic Creutzfeldt-Jakob disease. Brain 2009;132:2659-2668.

3. Berger JR, Aksamit AJ, Clifford DB, et al. PML diagnostic criteria: consensus statement from the AAN Neuroinfectious Disease Section. Neurology 2013;80:1430-1438.

4. Yousry TA, Pelletier D, Cadavid D, et al. Magnetic resonance imaging pattern in natalizumab-associated progressive multifocal leukoencephalopathy. Ann Neurol 2012;72:779-787.

5. Kappos L, Bates D, Edan G, et al. Natalizumab treatment for multiple sclerosis: updated recommendations for patient selection and monitoring. Lancet Neurol 2011;10:745-758.

6. Ladogana A, Puopolo M, Croes EA, et al. Mortality from Creutzfeldt-Jakob disease and related disorders in Europe, Australia, and Canada. Neurology 2005;64:1586-1591. 


\section{Neurology \\ Neuroimmunology \& Neuroinflammation}

\section{Unusual deterioration in a patient with multiple sclerosis on natalizumab therapy}

Thomas Gattringer, Christian Enzinger, Michael Khalil, et al.

Neurol Neuroimmunol Neuroinflamm 2014;1;

DOI 10.1212/NXI.0000000000000001

This information is current as of April 24, 2014

\section{Updated Information \& \\ Services}

References

Citations

Permissions \& Licensing

Reprints including high resolution figures, can be found at:

http://nn.neurology.org/content/1/1/e1.full.html

This article cites 6 articles, 0 of which you can access for free at: http://nn.neurology.org/content/1/1/e1.full.html\#\#ref-list-1

This article has been cited by 1 HighWire-hosted articles: http://nn.neurology.org/content/1/1/e1.full.html\#\#otherarticles

Information about reproducing this article in parts (figures,tables) or in its entirety can be found online at:

http://nn.neurology.org/misc/about.xhtml\#permissions

Information about ordering reprints can be found online: http://nn.neurology.org/misc/addir.xhtml\#reprintsus

Neurol Neuroimmunol Neuroinflamm is an official journal of the American Academy of Neurology.

Published since April 2014, it is an open-access, online-only, continuous publication journal. Copyright $(\subseteq$ 2014 American Academy of Neurology. All rights reserved. Online ISSN: 2332-7812.

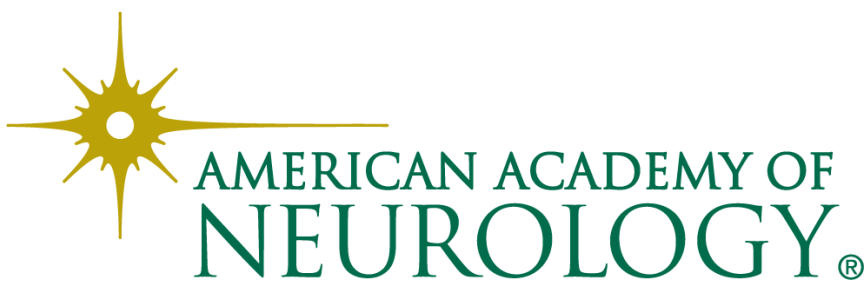

